\title{
Oliyev O.Q.
}

AMEA İnformasiya Texnologiyaları İnstitutu, Bakı, Azərbaycan

alovsat_qaraca@mail.ru

\section{İKT-yə ӘSASLANAN INNTELLEKTUAL COMIYYOTIN Və İQTISADIYYATIN FORMALAȘMASI XÜSUSIYYYOTLəRİ Və INNKISSAF PROBLEMLəRİ}

Daxil olmuşdur: 29.11.2020. Düzəliş olunmuşdur: 30.12.2020. Qəbul olunmuşdur: 04.01.2021.

Maqala IKT-yə, informasiyaya, bilik vo texnologiyalara ssaslanan intellektual comiyyatin vo iqtisadiyyatın formalaşmasının bəzi xüsusiyyətlarina va inkişafi problemlarinə hasr olunmuşdur. Yeni comiyyotin vo iqtisadiyyatın yaradılması, inkişaf etdirilməsi zərurəti vo aktuallığ asaslandırılmışdır. Postindustrial nozəriyyalarin istiqamatlari, informasiya, bilik va postbilik iqtisadiyyatları haqqında ümumi molumatlar şərh olunmuşdur. Postbilik iqtisadiyyatında intellektuallıq amili, bilik va postbilik iqtisadiyyatlarının asas farqli xüsusiyyətlari göstarilmişdir. Intellektual iqtisadiyyatın inkişafinın asas baza xüsusiyyətlari vo prinsiplari konseptual model formasında sxematik olaraq toklif olunmuşdur. Intellektual iqtisadiyyatın formalaşmasında institusional amillar va asas problemlar izah olunmuşdur. Intellektual iqtisadiyyatın formalaşması və inkişaf səviyyəsi üzra göstəricilərin işlənilmasinin ümumi istiqamətlari, xarakterləri müəyyənloşdirilmişdir. Intellektual camiyyətin və iqtisadiyyatın bəzi müasir inkişaf trendlarinin nəzərə alınması üçün müvafiq təklif va tövsiyalar verilmişdir. Maqaladə tədqiqat obyekti olaraq beynalxalq iqtisadi inkişaf meyllarinว, 4-cü Sənaye inqilabının çağırışlarına müvafiq olaraq intellektual comiyyatin va iqtisadiyyatın inkişafı problemlarinin müayyənlaşdirilməsində sistemli yanaşmadan istifado edilmişdir. Burada statistik analiz üsulları totbiq olunmuş, müasir IKT texnologiyalarının taləblari nəzərə alınmışdır. IKT-yə asaslanan intellektual cəmiyyətin vo iqtisadiyyatın formalaşması xüsusiyyatlari va inkişafi problemlarinin tahlili asasında verilan tövsiyalar yeni iqtisadiyyatın faaliyyatinin səmərali taşkilində müəyyən töhfalar vera bilar. Təklif olunmuş müasir iqtisadiyyatın formalaşmasının vo perspektiv inkişaf morhalalorinin konseptual modelinin nəzərə alınmasl yeni iqtisadi idarəetmədə qərar qabuluna alavə imkanlar yarada bilər.

Açar sözlor: informasiya iqtisadiyyatı, bilik iqtisadiyyatı, postbilik iqtisadiyyatı, intellektual iqtisadiyyat, innovasiya potensiall.

\section{Giriş}

Hər bir qabaqcıl ölkənin iqtisadiyyatının dayanıqlı və davamlı dinamik inkişafı onun gələcək inkişaf perspektivlərinin öncədən nəzərə alınmasını tələb edir. Odur ki, formalaşmaqda olan yeni iqtisadi sistem dünyanın inkişaf tendensiyalarını nəzərə almaq məcburiyyətindədir. Hər bir mərhələnin nə zamansa öz-özünə formalaşmasını indiki sürətli transformasiyalar şəraitində gözləmək olmaz. Hazırda dünyanın qabaqcıl dövlətləri informasiya və bilik iqtisadiyyatının müsbət nəticələrindən uğurla istifadə etməkdədirlər [1]. Ona görə də inkişaf etməkdə olan ölkə kimi Azərbaycan iqtisadiyyatının həm bilik, həm də ondan sonrakı mərhələsinin formalaşma və fəaliyyət xüsusiyyətlərinin [2] tədqiqinə və onların perspektiv inkişaf proqramlarında nəzərə alınmasına xüsusi ehtiyac vardır. Unutmaq olmaz ki, bu tələblər həm Milli informasiya cəmiyyətinin qurulması strategiyasında [3], həm də ölkə iqtisadiyyatının inkişafı üzrə Strateji Yol Xəritələrində [4] bir vəzifə olaraq göstərilmişdir.

\section{İnformasiya, bilik və postbilik iqtisadiyyatlarının xüsusiyyətləri və nəzəriyyələri}

Ümumiyyətlə, iqtisadiyyatın və iqtisad elminin əsas vəzifələri və təşəkkül mərhələləri haqqında onu qeyd etmək olar ki, hər hansı bir cəmiyyətdə iqtisadiyyat insanların birgə yaşayışını təmin edən təsərrüfat fəaliyyəti sahəsi kimi istehsal münasibətlərinin məcmusunu özündə əks etdirir [5]. Onun əsas vəzifəsi insanların müxtəliftəyinatlı tələbatlarını ödəmək üçün maddi- 
mənəvi nemətlər istehsal etmək və xidmətlər göstərməkdir. Әsas iqtisadi vəzifələr isə təbii resursların müəyyən məhdudluğu şəraitində insanların maddi, mənəvi tələbatlarının durmadan artması, hətta sonsuzluğa qədər yüksəlməsi fonunda onların daha dolğun, ədalətli, səmərəli ödənilməsidir. Başqa sözlə, iqtisadiyyat elmi insanların öz ehtiyaclarını təmin etmək məqsədilə məhdud resurslardan necə istifadə etməsi haqq1nda elm sahəsidir [6]. Onun əsas məqsədi iqtisadi hadisələr, proseslər arasındakı səbəb-nəticə əlaqələrini açıqlayan ümumiləşdirmələrin ortaya qoyulmasıdır. İqtisadiyyat elminin qanun və nəzəriyyələri iqtisadi prosesləri və meylləri az-çox müəyyən və dəqiq formada ifadə edir. Müasir anlamda iqtisad elmi mövcud resursların məhdudluğu və tələblərin sonsuzluğu şəraitində maddi nemətlərin, xidmətlərin istehsalı, bölgüsü, mübadiləsi, istehlakı prosesində insanların iqtisadi fəaliyyətinin təhlilidir. İqtisadiyyatın və müxtəlif iqtisadi nəzəriyyələrin qarşısında duran əsas problemlər "nə istehsal etməli?", "nə qədər istehsal etməli?", "necə istehsal etməli?", "kim üçün istehsal etməli?" kimi sualların həllinə çalışmaqdır. İqtisadi nəzəriyyənin bir elm kimi formalaşması XVI-XVII əsrlərdən başlayır. Kapitalizmin yaranması ilə iqtisadiyyat müstəqil elm sahəsi kimi formalaşmağa başlayır. İqtisad elminin XIX əsrdə inkişafı marksizm, marjinalizm, neoklassik nəzəriyyələrlə, XX əsrdə isə keynsçilik, neoliberalizm, monetarizm, institusionalizm kimi iqtisadi nəzəriyyələrlə bağlıdır. XX əsrin sonlarında və XXI əsrin əvvəllərində formalaşmaqda olan postsənaye iqtisadiyyatı müasir dövrümüzdə informasiya və biliklərə əsaslanan iqtisadi sistemlər kimi inkişaf etdi [5].

Ümumiyyətlə, informasiya iqtisadiyyatı, ümumi daxili məhsulun (ÜDM) 50\%-dən çox hissəsinin informasiyanın və biliyin istehsalı, emalı, mühafizəsi və yayılması sahəsində təmin olunduğu və əmək qabiliyyətli əhalinin yarıdan çoxunun bu fəaliyyətdə iştirak etdiyi iqtisadiyyatdır. $\mathrm{Bu}$ isə informasiya texnologiyalarının birbaşa inkişafı nəticəsində mümkün olur. Lakin bu iqtisadiyyatı bütövlükdə, kompüterlərin, telekommunikasiya avadanlıqlarının istehsalını və istifadə edilməsini, telekommunikasiya şəbəkələrinin inkişafını, proqram məhsulları və xidmətlərini və s. əhatə edən rəqəmsal iqtisadiyyat kimi qəbul etmək olmaz.

İnformasiya və bilik iqtisadiyyatında əmək və kapital aralıq resurs kimi mövcud bilikdən yeni biliklər formasında nəticə almağa xidmət edir. Burada bilik insanın intellektual fəaliyyətinin bir resursu, komponenti kimi çıxış edir. Rəqəmsal iqtisadiyyat da ümumilikdə iqtisadiyyatın, bir qədər də konkretləşdirsək, informasiya və bilik iqtisadiyyatının tərkib hissəsidir [7]. Bu istiqamətdə olan dövlət proqramları da intellektual kapitalın inkişafına yardım edir.

Sosial-iqtisadi inkişaf prosesi sənaye, postsənaye və bilik iqtisadiyyatları mərhələlərindən keçmişdir. $\mathrm{Bu}$ mərhələlərdə istehsalç1-istehlakçı münasibətlərində mülkiyyət məsələləri qisamüddətli, impulsiv xarakterdə olur və birindən digərinə keçmə inkişafda olmaqla baş verir. Sonrakı dövrlərdə isə mülkiyyət məsələlərinin xarakteri və müddəti ciddi dəyişir. İntellektual iqtisadiyyat dövründə müəssisələr yeni bilik istehsal edən, özünü və əməkdaşlarını intellektual inkişaf etdirən özünəməxsus tədqiqat mərkəzlərinə çevrilirlər [8]. Postbilik iqtisadiyyatı dövrü yaşayan ölkə bir növ alimlər ölkəsi kimi formalaşır və intellektual iqtisadiyyat kimi xarakterizə olunur. Perspektivdə isə əsas resurs və iqtisadi fəaliyyətin nəticəsi insanın intellektual fəaliyyətinin üzərinə düşəcəkdir .

Yeni iqtisadi sistemlər postsənaye iqtisadiyyatının müəyyən inkişaf mərhələsidir. D.Bell bu mərhələni "postindustrial cəmiyyət", P.Kats, M.Porat, U.Masuda və başqaları "informasiya cəmiyyəti", S.Bjezinski "texnotron cəmiyyət", L.Meyer, E.Giddens, L.Fideber, S.Kruk "postmodernizm", O.Toffler "sivilizasiyanın 3-cü dalğası", P.Draker "postkapitalist cəmiyyət" kimi təsvir və tədqiq etmişdilər. "Postindustrial cəmiyyət" anlayışı 1959-cu ildə Harvard Universitetinin professoru D.Bell tərəfindən elmə gətirilmişdir [9]. Postsənaye cəmiyyətinin yaranmasında mərkəzi yeri İKT tutur. İnformasiya iqtisadiyyatı nəzəriyyəsinin əsası Y.Şumpeter, F.Hayek, F.Maxlup tərəfindən qoyulub. F.Maxlup 1962-ci ildə nəşr olunmuş "Biliklərin istehsalı və yayılması sferası" kitabında biliklər sənayesini elmi araşdırmalar, təhsil, KIV, informasiya maşınları, informasiya xidmətlərindən ibarət olmaqla 5 qrupa bölmüşdür- İnformasiya iqtisadiyyatı termini 1996-1998-ci ildə İspaniya-Amerika iqtisadçısı Manuel Kastelsin 
"İnformasiya dövrü: iqtisadiyyat, cəmiyyət və mədəniyyət" adlı üçcildli monoqrafiyasının nəşrindən sonra geniş elmi dövriyyəyə daxil olmuşdur. Bu nəzəriyyə hələ də tam olaraq yaradılmamış və əksər iqtisadçılar tərəfindən bəyənilə bilən bitkin bir nəzəriyyə formalaşmamışdır. İnformasiya iqtisadiyyatı üzrə bəzi nəzəriyyələr və metodoloji yanaşmalar haqqinda [10] qisaca olaraq xatırlatmaq yerinə düşərdi ki, C.Helbreytin sənaye sistemi nəzəriyyəsinə görə sənaye sistemi yeni sənaye cəmiyyətinin təyinedici xassəsidir. D.Bellin postsənaye cəmiyyəti, həm də elə informasiya cəmiyyətidir. E.Tofflerin üçüncü dalğas1 sivilizasiyanın inkişafında üç mərhələni və ya üç dalğanı ayırd edir. U.Bekin risk cəmiyyətinə görə sərvətin ictimai istehsalı daim risklərin ictimai istehsalı ilə müəyyən olunur. M.Kastelsin informasiya cəmiyyətində informasiya iqtisadiyyatı qlobaldır. Qlobal iqtisadiyyat bütün planet miqyasında real vaxt rejimində vahid sistem kimi işləməyə qadirdir. V.İnozemtsevin postiqtisadi cəmiyyəti onunla xarakterizə olunur ki, cəmiyyətin iqtisadi əsaslarının dəf edilməsi sosial strukturların transformasiyası vasitəsi ilə deyil, fərdlərin mənəvi və intellektual təkamülü nəticəsində həyata keçirilə bilər. Z.Baumanın fərdiləşmiş cəmiyyəti əvvəlki və indiki cəmiyyətləri modern və postmodern kateqoriyalarında müqayisə edir.

Y.Şumpeterin novator sahibkar nəzəriyyəsi istehsalı mövcud resursların kombinasiyası kimi nəzərdən keçirir. Yeni məhsul istehsal etmək və ya yeni texnologiya tətbiq etmək resurslardan başqa kombinasiyalar yaratmaq, yəni, mahiyyətcə, əslində yeni informasiya yaratmaq deməkdir. Q.Bekkerin insan kapitalı nəzəriyyəsində bazar şəraitində işçinin məhsuldarlı̆̆ 1 onun əmək haqqının kəmiyyəti ilə eynidir. Məhsuldarlıq işçinin əlavə gəliri təmin edən bilik ehtiyatları ilə müəyyənləşir. M.Spensin siqnallar nəzəriyyəsinə görə əmək bazarı asimmetrik informasiyalı bazardır. Ona görə də işəgötürənlər işçilərin məhsuldarlığını xarakterizə edən informasiyanı qabaqcadan əldə etməyə çalışırlar. Bu cür informasiya siqnal adlandırılır. C.Stiqlerin informasiya axtarışı nəzəriyyəsi informasiyanı təsərrüfatçılıq subyektlərinin qazancı maksimallaşdırmaq üçün istifadə etdikləri spesifik resurs kimi nəzərdən keçirir. Subyekt axtarış nəticəsində informasiya əldə edir, bu zaman sərf olunmuş vəsaitlər isə xüsusi növ transaksiya məsrəfləri - axtarış məsrəfləri sayılır. Bunlarla yanaşı olaraq iqtisadiyyat üzrə bir çox Nobel mükafatı laureatlarının müvafiq nəzəriyyə, konsepsiya və tədqiqatları vardır ki, onları müəyyən dərəcədə informasiya iqtisadiyyatının formalaşması nəzəriyyələrinə aid etmək olar. Belə ki, ilk Nobelçi kimi 1969-cu ildə Yan Tinbergen (Hollandiya) və Raqnar Friş (Norveç) iqtisadi proseslərin təhlilinin riyazi metodlarını işləmişlər. 1970-ci ildə isə Pol Samuelson (ABŞ) iqtisad elmində elmi təhlilin səviyyəsinin yüksəldilməsinə nail olmuşdur. 1973-cü ildə Vasiliy Leontyev (ABŞ) "Xərclərburaxılış" ("Sahələrarası balans") metodunu işləmiş və iqtisadi problemlərin təhlilində tətbiq etmişdir. 1975-ci ildə Leonid Kantoroviç (SSRI), Tyallinq Kupmans (ABŞ) resurslardan optimal istifadə nəzəriyyəsini işləmişlər. 1987-ci ildə Robert Solou (ABŞ) iqtisadi artım nəzəriyyəsi sahəsində fundamental tədqiqatlarını həyata keçirmişdir. 2001-ci ildə Corc Akerlof (ABŞ), Mayk1 Spens (ABŞ), Djozef Ştiqlits (ABŞ) qeyri-simmetrik informasiyaların bazarda problemləri ilə bağlı nəzəriyyəni təklif etmişlər. 2017-ci ildə ABŞ-da Riçard Taler (Richard Thaler) - davranış iqtisadiyyatı sahəsində özünün elmi-metodoloji prinsiplərini şərh etmişdir. Bu nəzəriyyə və yanaşmaların hər biri informasiya iqtisadiyyatının formalaşmasında və inkişafında müəyyən əhəmiyyətə malikdirlər [5].

Müasir dövrümüzün və gələcəyin iqtisadi sistemi olan intellektual iqtisadiyyat yüksək inkişaf etmiş IKT və sistemləri şəraitində cəmiyyətin intellektual kapitalına əsaslanaraq ictimai inkişafın və rifahın artımını, beynəlxalq rəqabətqabiliyyətliliyini, innovativ biliyin geniş dövriyyəsini, təkrar istehsalını təmin etmək məqsədilə informasiya və bilikdən geniş istifadə edən, dəyişdirən, yenisini yaradan, yayan, inkişaf etdirən yeni iqtisadi sistemdir [11]. Bu iqtisadi sistemin əsasında bilik dayansa da, onun son məhsulu da elə bilik və innovasiyadır.

İntellektual iqtisadiyyatın formalaşdırılması üzrə konsepsiyaların işlənilməsi intellektual iqtisadiyyatın əsas məqsədləri, konstitutsion prinsipləri (dayanıqlı, davamlı inkişaf, innovasiyalılıq, inklüziv artım və s.), mühüm məsələləri (iqtisadi artımın yaşıllığı, resurslara 
qənaət, istehsal prosesinin intellektuallaşması, səmərəli bölgü və istehlak, sosial-iqtisadi təhlükələrin və problemlərin azaldılması və s.), formalaşma instrumentariyası (müxtəlif səviyyəli proqram xarakterli təşəbbüslərin qəbulu, müvafiq koordinasiya orqanlarının yaradılması, dayanıqlı investisiyalar mexanizminin işlənilməsi, informasiya və yüksək texnologiyaların inkişaf etdirilməsi, kiçik və orta biznesin inkişafı, ekoloji, sosial, innovasiyalı menecmentin həyata keçirilməsi, bərpa olunan enerjidən intensiv istifadə, təhsil və tədqiqatların keyfiyyət artımı və s.) və s. nəzərə alınmaqla yeni şəraitə uyğun formada həyata keçirilməlidir.

\section{Postbilik iqtisadiyyatında intellektuallıq amili}

Bilik və postbilik iqtisadiyyatının əsas xüsusiyyəti orada biliklər fəzasının daha da dərinləşməsi və genişlənməsidir. Qeyd etmək lazımdır ki, biliyə əsaslanan iqtisadiyyatın inkişafı üçün intellektual dəstəyin müəyyən kəmiyyət və keyfiyyət parametrləri vardır. Müəyyən sayda elmi kadrlar və ya onların həyata keçirdikləri innovativ layihələr istehsalın elmi intensivliyini artırmaq baxımından həmişə nəticə vermir. İntellektual dəstəyin keyfiyyəti intellektual kapitaldan istifadənin effektivliyi ilə yoxlanıla bilər [12].

İntellekt mövcud biliklərin sərhəddinin dərinləşdirilməsini, problemin mahiyyətinin dərkini, həmin problemin mövcud biliklərin terminoloji bazasında formulə edilməsini və qoyulmuş yeni problemin həllinə aparan cavab kimi təzə biliyin yaradılmasını özündə ehtiva edir. $\mathrm{Bu}$ isə o deməkdir ki, intellekt bəşəriyyəti dərk olunmayandan dərk olunana, bilinməzlikdən bilinənə, biliksizlikdən yeni biliyə aparan lokomotivdir, əsas hərəkətverici qüvvədir [13]. Müasir dünyada, məhz intellekt cəmiyyəti, o cümlədən elmi, texnologiyanı, iqtisadiyyat, siyasəti, mədəniyyəti, təhsili əsas müsbət istiqamətlərdə inkişaf etdirən vasitədir. Təsadüfi deyildir ki, hazırda intellekt anlayışı, nəinki insana, həmçinin texniki və sosiotexniki sistemlərə, qurğulara, şəhərlərə, dövlətə də aid edilməkdədir [13]. Bu nöqteyi-nəzərdən sistemin intellektliliyinə də aydınlıq gətirmək olar. Sistemi o zaman intellektual adlandırmaq olar ki, o, müstəqil olaraq biliksizlikdən yeni biliyə keçidi tələb edən problemli situasiyanı identifikasiya edə bilsin. Necə ki, biliklər bazası müstəqil olaraq modellərdə nəzərə alınan amillərin siyahısını genişləndirə bilir, yüksək intellektual sistemlər də əlavə tələb olunan bilikləri aşkara çıxara bilməlidir.

Sistemin intellekti verilmiş sistem iştirakçılarının intellektlərinin mürəkkəb inteqrasiyasıdır. Ancaq bu o zaman müsbət nəticəyə gətirir ki, bu inteqrativ birləşmə ayrı-ayrı iştirakçıların intellektual səviyyəsindən yüksək olsun. Başqa sözlə, cəmiyyətin, dövlətin əsas funksiyası ondan ibarət olmalıdır ki, cəmiyyət üzvlərinin elə qarş1lıqlı əlaqə strukturunu tapsın ki, cəmiyyətin intellektual səviyyəsi, onun hər bir üzvünün səviyyəsindən yüksək olsun, hər bir üzv isə öz səviyyəsini artıra bilsin. Bu missiya cəmiyyətin intellektual elitasının missiyasına çevrilməlidir.

\section{Bilik və postbilik iqtisadiyyatlarının fərqli xüsusiyyətləri və formalaşma mərhələləri}

İKT-nin təkmilləşdirilməsi, innovasiya texnologiyalarının sənayedə fəal tətbiqi, bazarların qloballaşdırılması və s. ilə əlaqədar olaraq yaranan yeni iqtisadiyyat postindustrial iqtisadiyyatın inkişaf pilləsi hesab oluna bilər. Yeni iqtisadiyyatın və postindustrial iqtisadiyyatın xüsusiyyətlərinin müqayisə edilməsi son nəticədə onların oxşar və fərqli cəhətlərini qiymətləndirməyə imkan verir. Ona görə də yeni iqtisadiyyata postindustrial cəmiyyətin ilkin mərhələsinin iqtisadiyyatının inkişaf modeli kimi baxmaq olar [14]. İnformasiya iqtisadiyyatı informasiya cəmiyyətinin iqtisadi bazisi kimi meydana gələrək sürətlə formalaşmağa başlamışdır. $\mathrm{O}$, elmi-texniki və sosial tərəqqinin qanunauyğun nəticəsi olaraq tamamilə obyektiv xarakter daşıyır. Aparılan təhlil və araşdırmalar nəticəsində bilik və postbilik iqtisadiyyatının əsas fərqli xüsusiyyətlərini Cədvəl 1-dəki kimi vermək olar.

İnformasiya və biliklər, eləcə də intellektual iqtisadiyyatı cəmiyyətin əvvəlki ənənəvi iqtisadi sistemlərinin sənaye inqilabları nəticəsində inkişafı kimi nəzərdən keçirərək, onların formalaşmasının və perspektiv inkişaf mərhələlərinin konseptual modelini sxematik olaraq Şəkil 1-dəki kimi ifadə emək olar. 
Modeldən göründüyü kimi 4-cü sənaye inqilab1 nəticəsində formalaşan innovativ informasiya iqtisadiyyatı yüksəkixtisaslı intellektual əmək resurslarına, intellektual qəbuletmə texnologiyalarına, o cümlədən Big data, cloud, soft computing, kiberfiziki sistemlər, 5G, süni intellekt, implant, yaşıl, pilotsuz idarəetmə, kosmik, blokçeyn və s. kimi ən müasir yeni nəsil İKT texnologiyalarına əsaslanmalıdır. Eyni zamanda 5-ci sənaye inqilabı nəticəsində formalaşan bilik və texnoloji tutumlu intellektual iqtisadiyyat dərin təlimlər, virtual reallıq sistemlərinə, yüksək süni intellektlərə, daha da yüksəkixtisaslı intellektual əmək resurslarına və koqnitiv texnologiyalara əsaslanacaqdir.

Cədvəl 1. Bilik və postbilik iqtisadiyyatının əsas fərqli xüsusiyyətləri

\begin{tabular}{|c|c|c|c|}
\hline Sira № & Osas xüsusiyyətlər & Bilik iqtisadiyyatında & $\begin{array}{c}\text { Postbilik } \\
\text { iqtisadiyyatında }\end{array}$ \\
\hline 1 & $\begin{array}{l}\text { İqtisadi inkişaf mərhələlərində } \\
\text { ardıcıllıq }\end{array}$ & $\begin{array}{l}\text { Postindustrialdan } \\
\text { sonrak1 }\end{array}$ & Bilikdən sonrakı \\
\hline 2 & İqtisadiyyatın tipi & Әmtəə iqtisadiyyatı & $\begin{array}{l}\text { Münasibətlər } \\
\text { iqtisadiyyatı }\end{array}$ \\
\hline 3 & Әsas resurs və əmtəə növü & İnformasiya və Bilik & Bilik və intellekt \\
\hline 4 & $\begin{array}{l}\text { İstehsalçı ilə istehsal məhsulu } \\
\text { arasındakı əlaqələrin xarakteri }\end{array}$ & $\begin{array}{l}\text { İstehsal məhsulu } \\
\text { istehsalçıdan ayrılır və } \\
\text { istehlakçının nəzarətinə } \\
\text { keçir }\end{array}$ & $\begin{array}{l}\text { İstehsal məhsulu həm } \\
\text { istehsalçının, həm də } \\
\text { istehlakçının } \\
\text { nəzarətində qalır }\end{array}$ \\
\hline 5 & $\begin{array}{l}\text { İstehsalçı və istehlakçı arasındak1 } \\
\text { əlaqənin xarakteri }\end{array}$ & $\begin{array}{l}\text { İmpulsivdir və } \\
\text { istehsaldan sonra } \\
\text { zəifləyir }\end{array}$ & $\begin{array}{l}\text { Sıx əlaqə vardır, əlaqə } \\
\text { kəsilmir və istehsalçı ilə } \\
\text { istehlakçının } \\
\text { intellektləri qarşılıqlı } \\
\text { təsirdə olurlar }\end{array}$ \\
\hline 6 & Osas tranzaksiyanın nəticəsi & $\begin{array}{l}\text { İstehlakçıda bilik } \\
\text { ehtiyatının artması }\end{array}$ & $\begin{array}{l}\text { İstehlakçıda və } \\
\text { istehsalçıda bilik } \\
\text { ehtiyatının artması, } \\
\text { onlar arasında dayanıql1 } \\
\text { əlaqənin qurulması }\end{array}$ \\
\hline 7 & $\begin{array}{l}\text { Cəmiyyətin intellektinin əsas } \\
\text { mənbəyi }\end{array}$ & Fərdi insanın intellekti & $\begin{array}{l}\text { Cəmiyyatin sistemli } \\
\text { intellekti }\end{array}$ \\
\hline 8 & Təhsilin əsas rolu və vəzifəsi & Biliyin alınması & $\begin{array}{l}\text { Sistemli insanın } \\
\text { formalaşması, sosial- } \\
\text { iqtisadi və sosiotexniki } \\
\text { sistemlərdə səmərəli } \\
\text { fəaliyyət göstərə bilən } \\
\text { iştirakçı insanın } \\
\text { yetişdirilməsi }\end{array}$ \\
\hline 9 & $\begin{array}{l}\text { Fərdi təhsilin səmərəlilik } \\
\text { kriteriyası }\end{array}$ & $\begin{array}{l}\text { Kompetentlik, } \\
\text { mütəxəssislik səviyyəsi }\end{array}$ & $\begin{array}{l}\text { Yeni intellektuallıq } \\
\text { səviyyəsi }\end{array}$ \\
\hline
\end{tabular}

4-cü sənaye inqilabı nəticəsində formalaşan innovativ informasiya iqtisadiyyatından 5-ci sənaye inqilabı nəticəsində formalaşan bilik və texnoloji tutumlu intellektual iqtisadiyyata keçid prosesi göstərir ki, IV sənaye inqilabının gətirdiyi yeniliklər müasir dövrdə yeni inqilabların yaranması, ona keçid üçün perspektiv imkanlar yaradır. Belə ki, IV sənaye inqilabında mövcud olan innovativ texnologiyaların struktur elementlərinin bir-biri ilə qarş1lıqlı əlaqədə olması, həmin elementlər arasında əlaqələrin daha da təkmilləşdirilməsi, texnoloji tutumlu intellektual iqtisadiyyat strukturunun və yeni texnologiyaların davamlı inkişafı yaxın gələcəkdə yeni inqilabın - V sənaye inqilabının formalaşmasına gətirib çıxarır. Qeyd etmək lazımdır ki, V sənaye 
inqilabının qloballaşan dünyada tətbiqi xüsusiyyətlərinin texnoloji tutumlu intellektual iqtisadiyyatda tətbiqi müasir dövr üçün əhəmiyyətli məsələlərdən hesab olunur.

\section{İntellektual iqtisadiyyatın əsas baza xüsusiyyətləri və prinsipləri}

"Postindustralizm"ə elmi ədəbiyyatlarda XX əsrin ikinci onilliyindən başlayaraq A.Kumaras və A.Pentinin əsərlərində rast gəlinmişdir. Daha çox P.Drukerin əsərində (1950) həmin keçidin səbəbləri izah edilmişdir. Bu nəzəriyyə sonralar 1962-ci ildə F.Maxlup tərəfindən inkişaf etdirildi. Ümumilikdə isə D.Bell 1959-cu ildə indiki anlamına müvafiq gələn "postindustrial cəmiyyət" termini istifadə edərək göstərdi ki, yeni cəmiyyətdə maddi istehsal öz aparıcı rolunu itirərək yerini qeyri-maddiyə verir. Bilik əsas istehsal qüvvəsinə çevrilir.

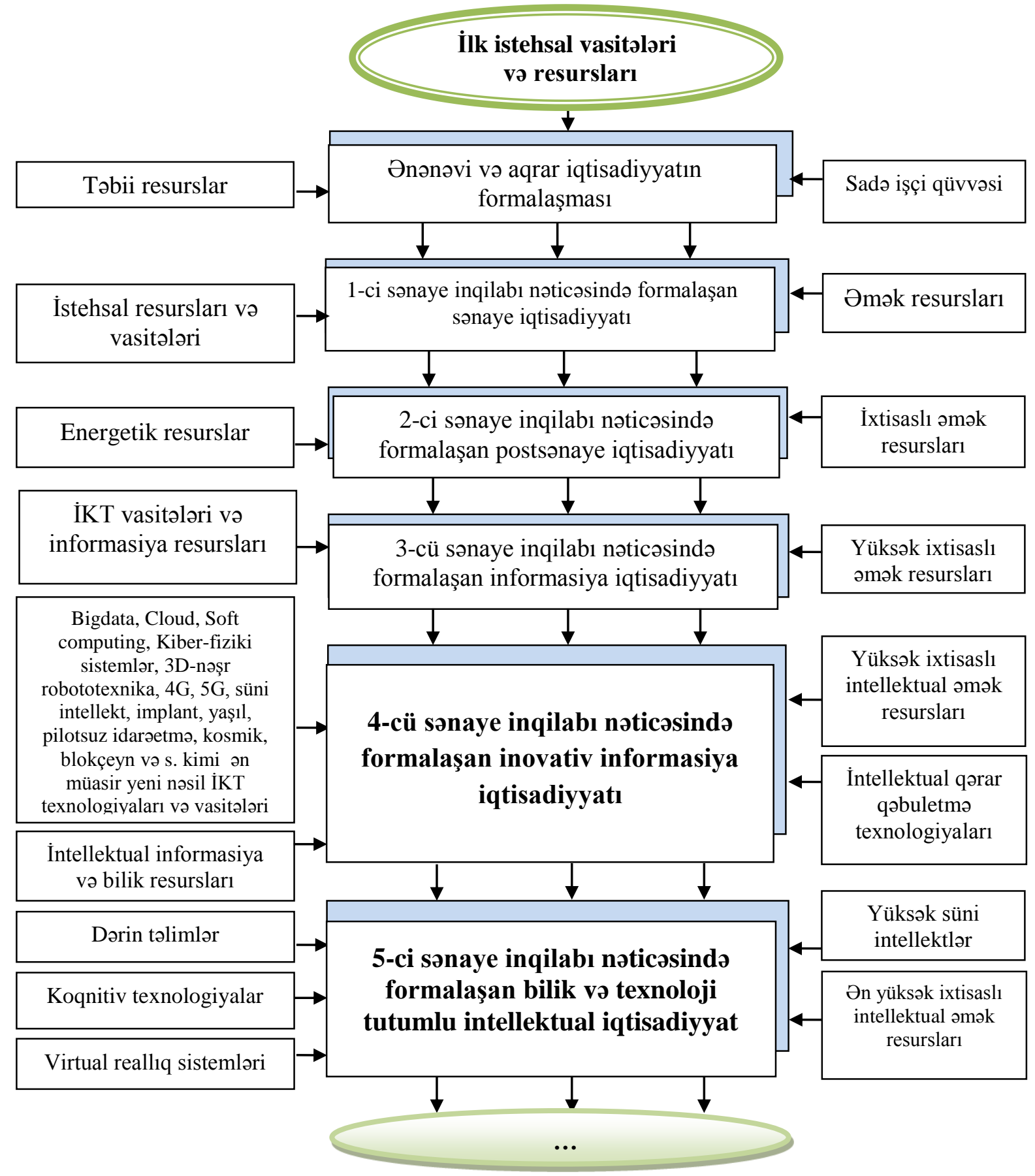

Şəkil 1. Müasir iqtisadiyyatın formalaşmasının və perspektiv inkişaf mərhələlərinin konseptual modeli 
1965-ci ildə ABŞ-ın Futuroloji Komissiyasında D.Bellin rəhbərliyi ilə insan kapitalının inkişaf konsepsiyası işlənilmiş və postindustrializm əsas inkişaf vektoru kimi təqdim edilmişdir. Sonralar 1973-cü ildə bu konsepsiya onun müvafiq əsərində öz əksini tapdı.

1980-ci illərdən başlayaraq postindustrial cəmiyyətdə informasiya iqtisadiyyatının formalaşmasına diqqət yönəltdilər. Bu istiqamətdə, həmçinin informasiya cəmiyyəti yanaşması da formalaşdırıldı. Y.Masuda, M.Kastels və digər alimlər informasiya iqtisadiyyatını qlobal iqtisadiyyat hesab edərək onun əsaslarını təhlil edirdilər $[15,16]$. Belə aydın olur ki, "intellektual iqtisadiyyat" termini özündə postindustrial, xidmət, yeni, informasiya, innovasiya, bilik, yaşıl, bio, dövri, kreativ, smart, əqli mülkiyyət iqtisadiyyatlarının qarşısında duran, onların əsas xüsusiyyətlərini özündə üzvi surətdə birləşdirən ən yeni iqtisadiyyatdır, iqtisadi sistemdir.

İntellektual iqtisadiyyat 4 əsas dayağa söykənir: təhsil sistemi, IKKT infrastrukturu, innovasiya sistemi, institutsional mühit. Yeni iqtisadiyyatın əsas prinsip və prioritetlərini bunlar əsasında formalaşdırmaq zəruridir:

$>$ İntellektuallaşma istiqamətində innovasiya əsaslı istehsala aparan layihələrə üstünlük verilməli, intellektual potensialı artırmalı, intellektual tələblər yaratmalı, innovativ texnologiyalar təkmilləşdirilməlidir.

> İnstitutsional istiqamətdə mülkiyyət münasibətləri, əqli mülkiyyət hüquqları, hüquqi baza, ətraf mühitə təsir təkmilləşdirilməlidir.

$>$ Ekologiya istiqamətində ekoloji-iqtisadi maraqları, təbii sistemin bütövlüyü, təbiətdən istifadə, ekoloji mədəniyyət, ekoloji infrastruktur inkişaf etdirilməlidir.

$>$ Sosial istiqamətdə əhalinin ümumi rifah halı yüksəldilməli, innovativ təhlükəsizlik, qarşılıqlı inam, təhsil, tibbi-sosial münasibətlər inkişaf etdirilməlidir.

Aparılan təhlillərin nəticəsi kimi intellektual iqtisadiyyatın əsas baza xüsusiyyətləri və prinsiplərini şəkil 2-dəki kimi ifadə etmək olar.

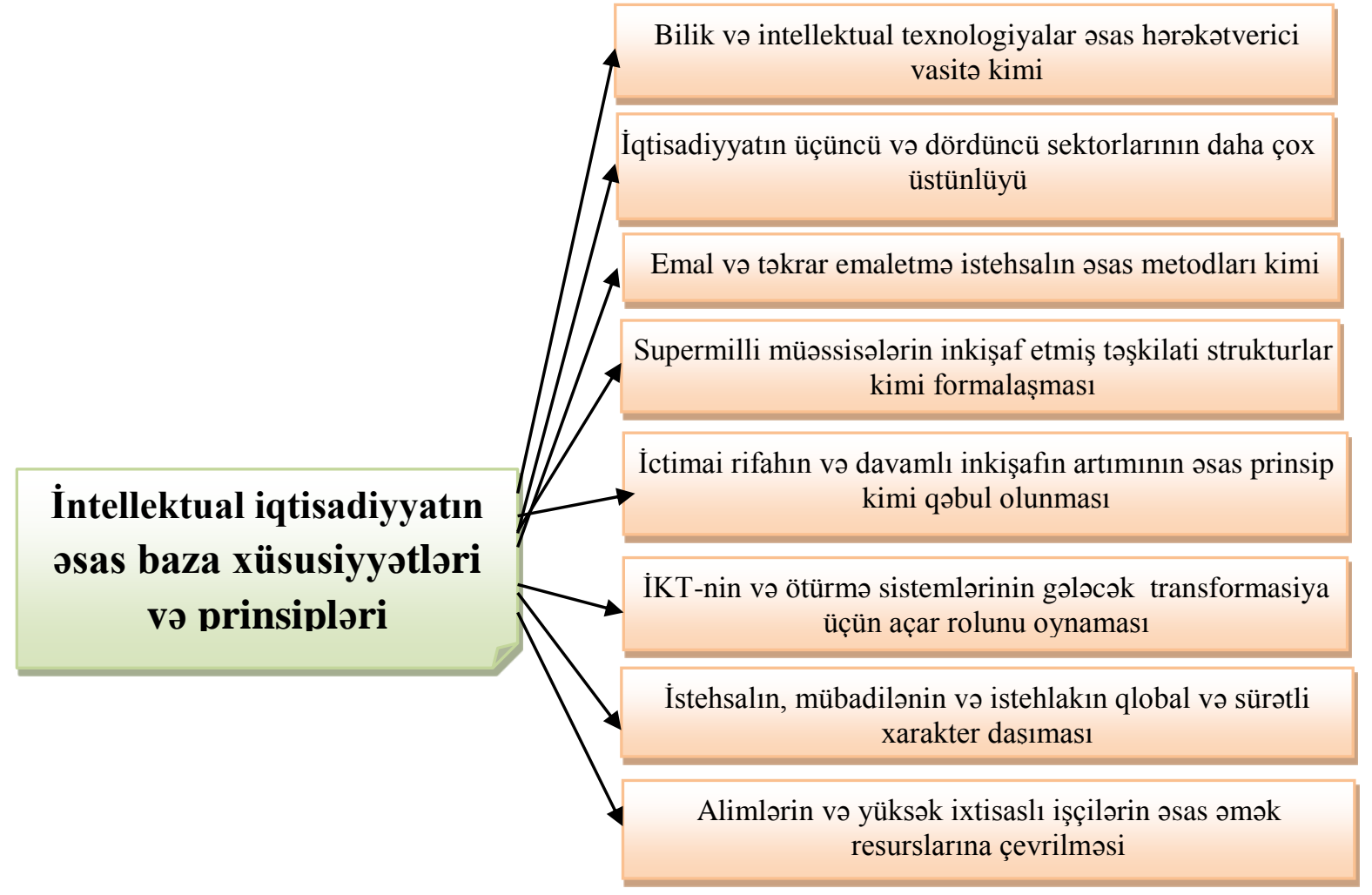

Şəkil 2. İntellektual iqtisadiyyatın inkişafının əsas xüsusiyyətləri və prinsipləri 


\section{İntellektual iqtisadiyyatın formalaşmasında institutsional amillər}

İqtisadiyyatın informasiyalaşdırılması nəticəsində formalaşan informasiya iqtisadiyyatı kompüter-şəbəkə texnikası, informasiya-kommunikasiya texnologiyaları və sistemləri əsasında texniki təchizat vasitələrinin tamamilə yenilənməsi informasiyanın birinci dərəcəli əhəmiyyətə malik iqtisadi resursa çevrilməsini nəzərdə tutur. İnformasiya iqtisadiyyatı mahiyyətinə görə, həm də bazar iqtisadiyyatıdır. O digər bazar sistemləri kimi istehlakçının müstəqilliyi ilə, azad innovativ müəssisənin olması ilə, müstəqil tipli bazarla, rəqabətlə, dövlətin onun işlərinə tam qarışmaması, sosial-iqtisadi tənzimlənməsi vasitələrinin tətbiqi ilə, növbəti sənaye inqilablarının komponentlərinin tətbiqi xüsusiyyətlərini nəzərə almaqla xarakterizə olunur.

Müasir iqtisadi sistemin formalaşmasında əsas rol oynayan institutsional mühit iqtisadi subyektlərin fəaliyyətinin təşkili formalarının və onların qarşılıqlı əlaqələrinin tənzimlənməsi normalarının, mexanizmlərinin toplusudur. İntellektual kapital təhsil, elm sferasında formalaşdırılsa da, istehsal-sənaye sferasında, sahibkarlıqda, səhiyyə sahəsində daha çox istifadə olunur.

İntellektual iqtisadiyyata keçmək üçün bəzi yollar təklif oluna bilər. İnstitutsional istifadə mühiti daha çox intellektual resurslardan istifadəyə doğru yönəlməlidir. Osas maraqlar əlavə dəyərin yaradılmasına fokuslanmalıdır. Regionlarda innovasiyalı inkişafa ciddi diqqət yetirilməlidir. Təbii resurslardan qənaətlə və məhdud istifadəyə görə normativ-hüquqi təminat təkmilləşdirilməlidir. İqtisadi vəziyyəti daimi izləmək üçün monitorinq sistemi işlənilməlidir. İntellektual sahibkarlıq tamamilə dəstəklənməli və sahibkarlı̆̆ın intellektuallaşması prosesi dərinləşdirilməlidir. Bilikdən istifadənin iqtisadi, sosial, ekoloji effektləri onun ölkə miqyasında əhəmiyyətinin artmasına gətirib çıxarmalıdır.

İnsanların intellektual potensialından istifadə səviyyəsi genişləndikcə iqtisadiyyat intellektuallaşır və yeni iqtisadi uklad formalaşır. Burada iqtisadi münasibətlər ənənəvi formatdan kənarlaşaraq insanların rifah halının daha da yaxşılaşmasına, maddi istehsalın, energetik resursların, ətraf mühitdən istifadənin ağıllı məhdudlaşdırılmasına, varlı və kasıb insan qrupları arasındakı uçurum fərqinin aradan qaldırmasına yönəlməkdədir.

İqtisadiyyatın intellektuallaşması bir çox sosial-iqtisadi münasibətlərin tənzimləyicisi faktoru kimi biliklərin istehsalı sferasını (elm), biliklərin təkrar istehsalını (təhsil), biliyin saxlanması (mədəniyyət), biliklərin yayılması (IKKT) sahələrini əhatə edir. Bu sahələrin və institutların fəaliyyəti cəmiyyətin və dövlətin qarşısında duran ən ümdə məsələlərin həllinə yönləndirilmolidir [17].

Qeyd edək ki, intellektual iqtisadi-biznes xidmətlərinin təşkili ölkənin innovasiyalı inkişafına və intellektual iqtisadiyyatın formalaşmasına müsbət təsir edir. Elmi biliklərin istehsalı iqtisadiyyatın modernləşməsinin səmərəsini artırır, proqnoz xarakterli analitik yanaşmalar, intellektual elementlər yeni texnoloji iqtisadi uklad mühitini formalaşdırır.

\section{İntellektual iqtisadiyyatın formalaşma və inkişaf səviyyəsi göstəricilərinin xüsusiyyətləri}

İntellektual potensialın və intellektual kapitalın qiymətləndirilməsində beynəlxalq təşkilatların mövcud metodoloji yanaşmalarının nəzərdən keçirilməsi belə qənaətə gəlməyə imkan verir ki, onların ölçülməsi üçün mövcud metodların müxtəlifliyi bəzi əsas amillərlə müəyyən edilir:

$\checkmark$ insanın yaradıcılıq qabiliyyətlərini ölçməyin mürəkkəbliyi;

$\checkmark$ yeni biliklərin iqtisadiyyata töhfəsini ölçməyin çətinliyi;

$\checkmark$ milli sosial-iqtisadi xüsusiyyətlərin spesifikliyi;

$\checkmark$ müasir informasiya texnologiyalarından istifadə dərəcəsi.

Biliklərə əsaslanan iqtisadiyyatın intellektual ehtiyatları ilə təmin edilməsi sahəsində təcrübə göstərir ki, dünyanın bir çox inkişaf etmiş ölkələri öz xammalları olmadan da iqtisadiyyatlarını uğurla inkişaf etdirir və əhali üçün yüksək həyat səviyyəsini təmin edirlər. Burada tipik nümunə Yaponiyadır. Yaponiyada iqtisadiyyatın texnoloji istiqaməti üstünlük təşkil edir. Xalqın 
intellektual imkanlarından səmərəli istifadə olunur ki, bu da ölkədə öz xammalının olmamasını kompensasiya edir. Bənzər vəziyyət, bu gün özünün texnoloji inkişaf strategiyasına güvənən Cənubi Koreya, Tayvan, Sinqapur və dünyanın bir çox digər ölkələrində müşahidə olunur.

Bizim ölkə üçün önəmli əhəmiyyət daşıyan keçmiş MDB-nin qabaqcıl regionlarında ali və orta ixtisas təhsili olan əhalinin payının yüksək olması orada iqtisadiyyatın texnoloji əsaslarının formalaşdırılması üçün intellektual potensialın mövcudluğunu göstərir [18, 19]. Bu mənbədən ÜDM-in artması üçün səmərəli istifadə etmək vacibdir, çünki bu gün qloballaşma, müasir informasiya texnologiyaları və 4-cü sənaye inqilabının təsiri altında insan əməyinin məhsuldarlı̆̆ və təbiəti ilə bağlı yanaşmalar dəyişir. Son onilliklər ərzində iqtisadi cəhətdən inkişaf etmiş ölkələrdə biliklərə əsaslanan yüksək texnoloji iqtisadiyyata keçid, insan inkişafı dayanıqlılığının və rifahının yüksəldilməsi istiqamətində dəyişmə müşahidə olunur.

Qeyd etmək lazımdır ki, son 5 ildə dünyada elm adamlarının ən yüksək nisbəti İsraildə müşahidə olunur. Belə ki, 2017-ci ildə 10 min nəfər üçün 135 elmi işçi çalışırdı, halbuki ABŞ-da bu rəqəm 85-dir. İntellektual iqtisadiyyatın formalaşması və inkişaf səviyyəsi göstəricilərinin işlənilməsinə olan yanaşmalardan biri də bu istiqamətdə ağıllı şəhərlərin formalaşma sürətinin yüksəldilməsinin və insanların həyat keyfiyyətinin artırılmasının nəzərə alınmasıdır [20]. İntellektual iqtisadiyyat konsepsiyasında iqtisadiyyat daha şəffaf, daha açıq, müxtəlif xarakterli olmaqla ağıllı şəhərlərə çox əhəmiyyət verilir, sahibkarlığa, innovasiyalara önəm verən əmək bazarının yaradılmasına, qlobal, yerli, regional əlaqələr hesabına məhsuldarlığın artmasına diqqət yetirilir.

İntellektual iqtisadiyyatın səviyyəsinin ölçülməsi üçün zəruri indikatorların, dəyişənlərin işlənilməsinə ehtiyac böyükdür. Bu prosesdə mövcud elmi metodologiya ilə yanaşı,həm də biznes, dövlət və vətəndaş cəmiyyəti baxışlarını da nəzərə almaq zəruridir. [21]-də müvafiq tədqiqatlar nəticəsində elə 34 göstərici və 10 dəyişən təklif olunmuşdur ki, onların vasitəsilə İndoneziyada ağıllı iqtisadiyyatın şəhər nümunəsində formalaşmasına qiymət vermək mümkün olsun. Hazırda İndoneziyada şəhər artımı illik 1,1 \% olmaqla digər Asiya ölkərindən çoxdur. Proqnozlar göstərir ki, 2025-ci ildə əhalinin 68\%-i şəhərlərdə yaşayacaqdır. Ölkə 2050-ci ildə şəhər əhalisi artımına görə Hindistan və Çindən sonrakı yeri tutacaqdır.

Oxşar sahədə elmi ədəbiyyatların təhlili göstərir ki, intellektual iqtisadiyyatın ölçülməsi sahəsində regional xüsusiyyətlərə malik standart göstəricilər yoxdur. Son ədəbiyyatlarda əsasən ümumi xarakterə malik olan sahibkarlıq, məhsuldarlıq, əmək bazarının çevikliyi, yenilikçilik, beynəlxalq səviyyəyə uyğunluq, transformasiya olunmaq bacarı̆̆ı, iqtisadi imic və əmtəə nişanları, turizm, yoxsulluq, imkanlar, e-biznes və s. kimi dəyişənlərdən istifadə olunmuşdur. Göstəricilər sırasına müvafiq olaraq elmi-tədqiqat və təcrübi-konstruktor işlərində xərclər, elmtutumlu sahələrdə məşğulluq səviyyəsi, patentlərin nisbi miqdarı, fərdi məşğulluq səviyyəsi, yeni biznes - iş yerləri, şəhər şirkətləri, birjaları, yük və sərnişinlərin avia daşınması, regional ÜDM və onun artım tempi, işçi qüvvəsinin iştirak səviyyəsi, əmək bazarında vakansiyalar, tam və natamam iş günləri olan məşğulluq səviyyəsi, əmək bazarının tənzimlənməsi, şəhərdə yoxsulluq/işsizlik faizi, mənzilə mülkiyyət faizi, Cinni əmsalı, qərar qəbuletmədə iştirak nisbəti, daxili/xarici turizm, milli brendlərin nisbəti, aktiv İnternet istifadəçiləri, qeyri-hökumət təşkilatlarının sayı/strukturu, rəqəmsal həllərin strukturu və s. daxildir. Tədqiqat prosesində intellektual mülkiyyət hüququ, eticarət, təhsilin əhatəliliyi, innovasiya üzrə dövlət proqramları, məzunlar, yeniliklər, kreativ iqtisadi imkanlar, asan kreditləşmə, tənzimlənmə, asan biznes, qeyri-rəsmi məşğulluq, kiçik və orta biznes beynəlxalq əməkdaşlıq, insan inkişafı, regional əmək haqq1, işsizlik səviyyəsi, əmək münaqişəsi, xoşbəxtlik indeksi, inflyasiya, iqtisadi infrastruktur, təhsil, İnternetin vəziyyəti, vətəndaş-hökumət münasibəti, IKT töhfəsi, bərpa olunan/olunmayan resurslar, yerli potensial, ətraf mühitə təsir və s. kimi göstəricilər də əlavə olunur.

ABŞ-1n İnnovasiya və İT Fondu 1999-cu ildən başlayaraq "Yeni iqtisadiyyat indeksi”ndən istifadə edir. Onun hesablanması üçün 5 kateqoriyada 25 göstəricidən istifadə olunur: əməkdaşların professionallığı; regionun qloballaşması; startapları və digər proqressiv strukturları 
əhatə edən iqtisadi dinamika; iqtisadiyyatın informasiyalaşması və innovasiya potensialı; yeni əmtəə və texnologiyaların yaradılması üçün zəruri bazanın olması.

İqtisadiyyatın mikrosəviyyədə intellektuallıq səviyyəsi göstəricilərindən biri də Tobin əmsalıdır. $\mathrm{O}$, müəssisənin bazar qiymətinin, onun real aktivlərinin əvəzlənməsi qiymətinə olan nisbəti kimi xarakterizə edilir. Qiymətlər fərqliliyi müəssisənin intellektual kapitallığını, bilikliliyini göstərir. Tobin əmsalı bilik iqtisadiyyatı müəssisələrində 1-dən böyük, ənənəvilərdə isə kiçikdir [21].

\section{Intellektual iqtisadiyyatın bəzi trendləri}

Bu sahədə dövlət sifarişinin artırılması istiqamətində görülən tədbirlərə baxmayaraq, elmi fəaliyyət bir çox gənclər üçün cəlbedici olmamağa davam edir. Elmi işlər görmək üçün xaricdə daha cəlbedici maddi şəraitin olması xaricə "beyin axını"nı ölkə üçün əhəmiyyətli bir problemə çevirir. Qazaxıstan bölgələrində ixtisaslı kadrlar ölkə paytaxtına getdikcə regionlarda daha da böyük kadr çatışmazlığı yaranır. Aydındır ki, akademik fəaliyyəti stimullaşdırmaqla yanaşı, xaricdən elmi kadrların cəlb olunmasına töhfə verən institutsional tədbirlər də görülməlidir.

Bilik iqtisadiyyatında intellektual tədqiqat və biliklərə tələbat daim artır. Yüksək inkişaf etmiş ölkələrdə bu, elmin maliyyələşdirilməsi və alimlərin əmək haqlarının iqtisadiyyat üçün orta səviyyəyə nisbətdə daim artması ilə ifadə olunur. Qazaxıstan və bu kimi bir çox ölkələrdə elmə investisiya qoyuluşu ümumdünya meylindən xeyli aşağıdır.

Qeyd edək ki, Sənaye 4.0-1n inkişaf paradiqması, intellektual kapitaldan istifadənin keyfiyyəti və səmərəliliyi ilə təmin olunan resurs bazası üçün yeni tələbləri müəyyənləşdirir. Bu fakt Qazaxıstan kimi ölkələrin təbii ehtiyatlarının hasilatı və ixracı hesabına gələcək iqtisadi artımını obyektiv şəkildə məhdudlaşdırır və aparıcı prinsip üzrə elmin maliyyələşdirilməsinin zəruriliyini aktuallaşdırır.

Yeni iqtisadiyyatın formalaşması bir çox trendlərdə müşahidə olunur [18, 22, 23]. Təhsilin, elmi-tədqiqatların, innovativ işləmələrin sürətli inkişafı belə istiqamətlərdəndir.

Ölkənin ixrac potensialının artırılmasında ağıllı iqtisadiyyatın töhfəsi çox ola bilər. Çin iqtisadiyyatının nümunəsində bu proses təhlil olunaraq göstərilir ki, yaranmış Çin-ABŞ ticarət krizisindən ağıllı iqtisadiyyat prinsipləri əsasında yeni sərbəst iqtisadi zonaların və əlverişli ticarət mühitinin yaradılmasıyla çıxmaq və region ölkələri ilə ticarət əlaqələrini genişləndirmək mümkündür. Hazırkı dövrdə Yaponiya hökuməti ciddi sosial-iqtisadi məsələlərin həllinə yönəlmiş texnoloji innovasiyalara əsaslanan super ağlllı cəmiyyət qurmaq üçün "Comiyyət 5.0" siyasi proqramları icra etməkdədir [24]. Bu proqram ilk növbədə 4.0 sənaye inqilabı texnoloji innovasiyaları olan Oşyaların İnternetinə, böyük verilənlərə, süni intellektə, robotlara, birgə istifadə iqtisadiyyatına, kütləvi rəqəmsallaşmaya əsaslanmaqla daimi olaraq yeni dəyərlər, xidmətlər yaradır, həyatı daha rahat, daha etibarlı və dayanıqlı edir. Oxşar proqramlar Çin, ABŞ və Avropa ölkələrində də vardır.

\section{Naticə}

Təhlillər göstərir ki, XXI əsrin texnoloji trendləri istehsalın və istehlakın təşkilinə tələbləri sərtləşdirir. Nanomaterialların, biotexnologiyaların, alternativ enerji mənbələrinin, yüksək informasiya-telekommunikasiya, kosmik, idarəetmə, IoT, kiber-fiziki sistemlər, Big data, cloud və s. kimi texnologiyaların geniş tətbiqi sivilizasiyanın inkişafına həm mənfi, həm də müsbət istiqamətlərdə təsir etməkdədir. Ona görə də belə şəraitdə iqtisadi fəaliyyət subyektlərinin, vətəndaş cəmiyyəti institutlarının üzərinə sosial-iqtisadi münasibətlərin tənzimlənməsi üzrə daha ciddi vəzifələr düşür. Bu vəzifələrin zamanında yerinə yetirilməsi iqtisadiyyatın və cəmiyyətin intellektual texnologiyalar əsasında inkişaf etdirilməsinə və daha ciddi müsbət iqtisadi nəticələrin alınmasına gətirəcəkdir. 


\section{Odəbiyyat}

1. Клейнер Г.Б. Интеллектуальная экономика нового века: Экономика постзнаний // Экономическое возрождение России, 2020, №1(63), с. 35-42.

2. Azərbaycan - 2020: Gələcəyə Baxış" İnkişaf Konsepsiyası. Bakı, 29 dekabr 2012, https://president.az/files/future_az.pdf

3. Azərbaycan Respublikasında İnformasiya Cəmiyyətinin İnkişafina dair 2014-2020-ci illər üçün Milli Strategiya. Bak1, 02 aprel 2014, https://president.az/articles/11312.

4. Azərbaycan Respublikasının milli iqtisadiyyat perspektivi üzrə Strateji Yol Xəritəsi. Bakı, 6 dekabr 2016, https://president.az/articles/21953.

5. Oliyev Ә.Q. İnformasiya iqtisadiyyatı sektorlarının formalaşmasının elmi-nəzəri və metodoloji əsaslarının tədqiqi // İnformasiya cəmiyyəti problemləri, 2018, №2, s. 84-96.

6. Проблемы экономического роста в странах Центрально-Восточной Европы в условиях новой реальности в мировой экономике. Отв. ред. Н.В. Куликова, М., ИЭ РАН, 2019, 366 c., http://www.inecon.org.

7. Hideaki U.H. The big push to a knowledge-based economy with intellectual property rights protection // Review of Development Economics, 2020, vol.24, issue 4, pp.1551-1559.

8. Nikitenko S.M., Mesyats M.A. Intellectual property rights as the resource for innovative economy development / IOP Conference Series: Earth and Environmental Science, SibSIU, Novokuznetsk, Russia, 4-7 june 2019, volume 377, pp.1-8.

9. Безруких Д.В. Информационная экономика как драйвер инновационного развития экономики РФ // Проблемы современной экономики, 2016, №35, с.116-120.

10. Farshad F.M., Nasser E. et al. Appropriate theoretical framework for understanding and analyzing economic issues in knowledge-based economy // Journal of the Knowledge Economy, 2017, vol. 8, issue 3, pp.957-976.

11. Джигеров 3.А., Дубовик М.В. Новые тренды в интеллектуальной экономике // Экономика устойчивого развития, 2013, №13, с.82-87.

12. Doguchaeva S.M. Intellectual components of digital automation in economics // Economy Business Banks, 2018, issue 1, pp. 96-104.

13. Ишназарова 3.М. Экономика России: Место интеллектуального развития и знаний // Вестник ПНИПУ. Социально-экономические науки, 2017, №1, с.164-180.

14. Oliyev Ә.Q. Müasir şəraitdə informasiya iqtisadiyyatının formalaşma xüsusiyyətləri və problemləri // AMEA-nın Xəbərləri. İqtisadiyyat seriyası, 2018, №1, s.34-45.

15. Замлелый A.Ю. Формирование SMART (интеллектуальной) экономики: теория и практика // Современные проблемы науки и образования, 2012, №4, http://www.scienceeducation.ru/ru/article/view?id=6684.

16. Andrew W. Manuel Castells's trilogy the information age: economy, society, and culture // Information Communication \& Society, 2016, vol. 19, issue 12, pp.1673-1678.

17. Паньшин Б. Интеллектуальный каркас экономики. наука и инновации // Наука и инновации, 2014, №10(140), с. 48-52.

18. Sagiyeva R., Zhuparova A., Ruzanov R., Doszhan R., Askerov A. Intellectual input of development by knowledge-based economy: problems of measuring in countries with developing markets // The International Journal Entrepreneurship and Sustainability, 2018, vol. 6, No 2, pp.711-728.

19. Centre for the Fourth Industrial Revolution Network, 2019, $24 \mathrm{p}$.

20. Vinod T., Kumar M., Dahiya B. Chapter 1. Smart Economy in Smart Cities // Springer Nature Singapore, 2017, pp.3-76.

21. Indrawati I., Azkalhaq N., Amani H. Indicators to measure smart economy: An Indonesian perspective / ICBIM '18: Proceedings of the 2nd International Conference on Business and Information Management, 2018, september 20 22, pp.173-179. 
22. Orlovska Y., Cherchata A., Kovalenko O. Development of intellectual economy: some approaches for policy elaborating // Baltic Journal of Economic Studies, 2020, vol.6, No. 2, pp. 116-124.

23. Kupriyanova L.M., Usmanova T.H. The special aspects of the intellectual property economics // Economy Business Banks, 2016, issue 3, pp. 81-94.

24. Holroyd C. Technological innovation and building a 'super smart' society: Japan's vision of society 5.0. // Journal of Asian Public Policy, 2020, pp.1-14.

\section{УДК 330.1:004}

\section{Алиев Аловсат $\Gamma$. \\ Институт Информационных Технологий НАНА, Баку, Азербайджан \\ alovsat_qaraca@mail.ru}

\section{Особенности проблемы развития интеллектуального общества и экономики на основе ИКТ}

Статья посвящена некоторым особенностям формирования и развития интеллектуального общества и экономики, основанной на ИКТ, информации, знаниях и технологиях. Обоснованы необходимость и актуальность создания и развития нового общества и экономики. Объясняются общие направления постиндустриальных теорий, информации, знаний и постиндустриальной экономики. Показаны интеллектуальный фактор в экономике постзнания, основные отличительные черты экономики знаний и экономики постзнания. В виде концептуальной модели схематично предложены основные базовые черты и принципы развития интеллектуальной экономики. Разъяснены институциональные факторы и основные проблемы формирования интеллектуальной экономики. Определены общие направления и характеристики разработки индикаторов формирования и уровня развития интеллектуальной экономики. Сделаны соответствующие предложения и рекомендации с учетом некоторых современных тенденций развития интеллектуального общества и экономики. В статье использован системный подход к выявлению проблем интеллектуального общества и экономического развития в соответствии с тенденциями международного экономического развития, вызовами 4.0 промышленной революции. Здесь применены методы статистического анализа, учтены требования современных ИКТтехнологий. Рекомендации, основанные на анализе особенностей формирования и проблем развития интеллектуального общества и экономики, основанной на ИКТ, могут внести определенный вклад в эффективную организацию новой экономики. Учет предложенной концептуальной модели становления современной экономики и этапов перспективного развития может создать дополнительные возможности для принятия решений в новом хозяйственном управлении.

Ключевые слова: информационная экономика, экономика знаний, экономика постзнаний, интеллектуальная экономика, инновационный потенциил. 
Alovsat G.Aliyev

Institute of Information Technology of ANAS, Baku, Azerbaijan

alovsat_qaraca@mail.ru

Features of the problem of the development of the ICT-based intellectual society and economy

The article is devoted to some of the features of the formation and development of an intellectual society and economy based on ICT, information, knowledge and technology. The necessity and urgency of the creation and development of a new society and economy are substantiated. The paper explains the general directions of post-industrial theories, information, knowledge and postindustrial economics. The intellectual factor in the post-knowledge economy, the main distinctive features of the knowledge economy and the post-knowledge economy are shown. In the form of a conceptual model, the basic features and principles of the development of the intellectual economy are schematically proposed. The institutional factors and the main problems of the formation of the intellectual economy are clarified. The general directions and characteristics of the development of indicators for the formation and level of development of the intellectual economy are determined. Certain proposals and recommendations are made taking into account some modern trends in the development of the intellectual society and economy. The article uses a systematic approach to identifying the problems of an intellectual society and economic development in accordance with the trends of international economic development, the challenges of Industry 4.0 revolution. The methods of statistical analysis are applied here, the requirements of modern ICT technologies are taken into account. Recommendations based on the analysis of the peculiarities of the formation and development problems of ICT-based intellectual society and economy can contribute to the effective organization of the new economy. Taking into account the proposed conceptual model of the formation of the modern economy and the stages of further development can create additional opportunities for decision-making in the new economic management.

Keywords: information economy, knowledge economy, post-knowledge economy, intellectual economy, innovation potential. 